\title{
Mean components for choosing maize populations to extract inbred lines
}

\section{Componentes de média para escolha de populações de milho para extração de linhagens}

\section{Ewerton Lélys Resende ${ }^{*}\left(\mathbb{D}\right.$, Renzo Garcia Von Pinho ${ }^{2}$, Eric Vinicius Vieira Silva ${ }^{1}\left(\mathbb{D}\right.$, João Júlio Massitela ${ }^{3}$, Vander Fillipe de Souza² $\mathbb{D}$, João Lucas Dias Souza² $\mathbb{D}$}

\author{
'Universidade Federal de Lavras/UFLA, Departamento de Biologia/DBI, Lavras, MG, Brasil \\ ${ }^{2}$ Universidade Federal de Lavras/UFLA, Departamento de Agricultura/DAG, Lavras, MG, Brasil \\ Instituto de Investigação Agrária de Moçambique, Maputo, Moçambique \\ ${ }^{*}$ Corresponding author: elresendeagro@outlook.com \\ Received in June 30, 2020 and approved in October 8, 2020
}

\begin{abstract}
The choice of germplasm is one of the most important phases of a genetic improvement program to the fact that it is the initial development stage of superior hybrids. Hence, the objectives of this study were to obtain the estimates of $m+a$ and $d$, and inbreeding depression for grain yield and plant height traits, for cultivars lacking this information, and thus to predict the potential of maize hybrids for the extraction of lines. The $F_{1}$ and $F_{2}$ generations of 12 maize hybrids were tested at two sites, during the crop years of 2017-18 and 2018-19, accounting for four environments. Both the generations were evaluated in contiguous experiments in randomized blocks design with three and two repetitions during the years 2017-18 and 2018-19, respectively. The data on plant height and grain yield were collected, per plot, from both the generations, utilizing which, the $m+a$ and $d$ mean components were estimated. The effects of dominance had greater importance for the character grain yield. The most promising hybrids for extraction of lines were AG1051, AG8025, BG7046, DKB455, and OMEGA due to their greater estimates of $m+a$. The hybrids AG8025 and BG7046 were associated with high values of $m+a$ and grain yield. For the plant height trait, there was a greater contribution of additive effects. Therefore, greater inbreeding depression was observed for the grain yield trait when compared to the height of the plant.
\end{abstract}

Index terms: Zea mays, L.; heterosis; inbreeding depression.

\section{RESUMO}

A escolha do germoplasma é uma das fases mais importantes do programa de melhoramento genético do milho pois é o início do desenvolvimento de híbridos superiores. Em vista disso, os objetivos deste estudo foi obter as estimativas de $m+a$ e $d$, e a depressão por endogamia para as características produtividade de grãos e altura de plantas, e assim predizer o potencial dos híbridos de milho para extração de linhagens. Foram testadas as gerações $F_{1}$ e $F_{2}$ de 12 híbridos de milho, em dois locais durante os anos agrícolas de $2017 / 18$ e 2018/19, contabilizando quatro ambientes. As duas gerações, $F_{1}$ e $F_{2^{\prime}}$ foram avaliadas em experimentos contíguos no delineamento de blocos casualizados, com três e duas repetições durante os anos 2017/18 e 2018/19, respectivamente. Foram coletados dados de altura de plantas e produtividade de grãos por parcela das duas gerações, e a partir destes dados, foram estimados os componentes de média, $m+a$ e $d$, para ambas características. Para o caráter produtividade de grãos, os efeitos de dominância apresentaram maior importância. Os híbridos mais promissores para extração de linhagens foram AG1051, AG8025, BG7046, DKB455 e OMEGA uma vez que apresentaram maiores estimativas de $m+a$. Destacando-se os híbridos AG8025 e BG7046 os quais mostraram altos valores de $m+a$, além de médias de produtividade elevadas. Para o caráter altura de plantas, houve maior contribuição dos efeitos aditivos. Portanto, observou-se maior depressão por endogamia para o caráter produtividade de grãos quando comparado com altura de plantas.

Termos para indexação: Zea mays, L.; heterose; depressão por endogamia.

\section{INTRODUCTION}

Maize crop has great importance in food security and economic development of many countries. Due to the actual global scenario, which involves climate changes, population growth, increasing demand for quality foods, and others, the importance of genetic improvement of maize will increase in the near future. In Brazil, maize production had significant growth in maize productivity due to an increase of $348 \%$ in the last 41 years (Companhia Nacional de Abastecimento, CONAB, 2019). 
The development of superior genotypes is an extensive and long-term process; thus, it is crucial to pay attention to the choice of base populations since they are essential to plant breeding programs (Hallaeuer et al., 2010). The choice of base populations has to be based on very clear goals and focused on a few traits, aiming to get segregating populations with high grain yield means, and also variability for the traits under selection. Since most plant traits of commercial interest have complex genetic controls, the definition and choice of the best parental becomes a difficult task (Ramalho et al., 2012).Toto circumvent these challenges, one of the procedures that help the breeders is the estimation of $m+a$ and $d$, as proposed earlier by Vencovsky and Cruz (1991). This method allows us to evaluate the potential of early generations more simply, thereby facilitating the choice of new populations to be used, and thus reducing the costs and time to obtain the hybrids. The $m+a$ component corresponds to the mean of all lines in Fo generation, while $d$ represents the variabilities between the lines. Therefore, in order to obtain the lines with good agronomic performance, high values of $m+a$ and $d$ are desirable.

This methodology has been widely adopted by several authors earlier, aiming to obtain the best populations for line extraction, and consequently reducing self-fertilization and evaluation costs of lines (Kuki et al., 2017). However, due to the dynamic of hybrid releases in the market, many maize hybrids do not have information about either their inbreeding depression or $m+a$ and $d$, even in the case when this information is very valuable to initiate new breeding populations and continue the breeding cycles.
Hence, the objectives of this study were to obtain $m+a$ and $d$ estimates, as well as the inbreeding depression for grain yield and plant height traits, and thus to predict the potential of commercial maize hybrids for new lines extraction.

\section{MATERIAL AND METHODS}

The experiments were conducted at two sites, namely, the Center of Scientific and Technological Development in Agriculture of the Federal University of Lavras (UFLA), lat. $21^{\circ} 20^{\prime} \mathrm{S}$ and long. $44^{\circ} 98^{\prime} \mathrm{W}$, at 918 $\mathrm{m}$ of altitude, and the experimental area of the Agriculture Department of UFLA, lat. $21^{\circ} 13^{\prime} \mathrm{S}$ and long. $44^{\circ} 58^{\prime} \mathrm{W}$, at $919 \mathrm{~m}$ of altitude, both located in the southern region of the state of Minas Gerais, Brazil.

Twelve commercial maize hybrids, which have not been characterized for promising inbred lines extraction, were used in correspondence to their $F_{1}$ generation (Table 1). The $\mathrm{F}_{2}$ generation was obtained by self-pollinization of twenty-five plants, on average, of each $\mathrm{F}_{1}$ hybrid during the 2016-17 crop season.

In comparison, the data to obtain the $m+a$ and $d$ estimates, in the $F_{1}$ and $F_{2}$ generations, were evaluated under two experiments, which were carried out during two agricultural years 2017-18 and 2018-19. The seeds were sown on November 24th, 2017 and November 26th, 2018, respectively. The combination of the two sites and the two agricultural years accounted for four environments were: 1-Muquém (2017/18); 2-UFLA (2017/18); 3-Muquém (2018/19), and 4-UFLA (2018/19).

Table 1: Identification and main characteristics of $F_{1}$ commercial hybrids.

\begin{tabular}{ccccc}
\hline Hybrids & Company & Cycle $^{1}$ & Texture of the grain & Type of hybrid \\
\hline AG1051 & Agroceres & Semi-early & Dent & Double-cross \\
AG5055 & Agroceres & Early maturity & Dent & Three-way cross \\
AG8025 & Agroceres & Early maturity & Dent & Single-cross \\
Alfa_9020C & Alfa Pesquisa e Sementes & Early maturity & Semi-hard & Single-cross \\
BG7046 & Biogene & Super early & Semi-hard & Single-cross \\
BM810 & Biomatrix & Early maturity & Semi-hard & Single-cross \\
2B587 & Dow AgroSciences & Early maturity & Semi-Dent & Single-cross \\
DKB455 & Dekalb & Early maturity & Semi-hard & Three-way cross \\
Impacto & Syngenta & Early maturity & Hard & Single-cross \\
Omega & Syngenta & Early maturity & Hard & S. Modified \\
PRE_32D10 & Prezzotto & Early maturity & Semi-hard & Double-cross \\
RK3014 & Riber-KWS & Early maturity & Hard & Three-way cross \\
\hline
\end{tabular}

Source: Author's (2019). ${ }^{1}$ Data provided by the company. 
The experiments of $F_{1}$ and $F_{2}$ generations were contiguous, conducted through randomized blocks design with three and two repetitions for the agricultural years of 2017-18 and 2018-19, respectively. The two $4 \mathrm{~m}$ wide rows plots spaced in $0.6 \mathrm{~m}$ apart from each other were adopted. Additionally, extra maize plants were thinned manually to get a population of 60000 plants per hectare for each plot. Due to the planting, $400 \mathrm{~kg} \mathrm{ha}^{-1}$ of formulated fertilizer, 08-28-16 ( $\left.\mathrm{N}, \mathrm{P}_{2} \mathrm{O}_{5}, \mathrm{~K}_{2} \mathrm{O}\right)$, and other micronutrients were used. The top application of dressing fertilizer was 300 $\mathrm{kg} \mathrm{ha}^{-1}$ of 20-00-20 (N, $\left.\mathrm{P}_{2} \mathrm{O}_{5}, \mathrm{~K}_{2} \mathrm{O}\right)$. The other farming practices were conducted according to the necessities of the crop, climate, and location.

Grain yield data were collected for each plot $\left(4.8 \mathrm{~m}^{2}\right)$, and humidity corrections $(13 \%)$ were also performed. Plant stand corrections to 60000 plants were done through Vencovsky and Cruz (1991) method to obtain accurate in $\mathrm{kg} \mathrm{ha}^{-1}$. For plant height trait, which corresponds to the distance between the ground level and the insertion of flag leaf, data from five random plants per plot were collected.

The $m+a$ and $d$ estimates were obtained by following estimators, $m+a=\left(2 \times \bar{F}_{2}\right)-\bar{F}_{1}, \quad d=2\left(\bar{F}_{1}-\bar{F}_{2}\right)$, in which $\bar{F}_{1}$ and $\bar{F}_{2}$ represent the means of $\mathrm{F}_{1}$ and $\mathrm{F}_{2}$ generations for an evaluated trait, respectively. It was also estimated that the mean of inbreeding depression in percentage by the estimator $\left[\left(\overline{F_{1}}-\overline{F_{2}}\right) \div \overline{F_{1}}\right] \times 100$. The collected phenotypic data were submitted for analysis of variance using the package agricolae (Mendiburu, 2019) in the R software (R Core Team, 2019). The grain yield and the plant height means of the treatments were grouped by the Scott-Knott method. The experimental precision was verified through estimates of accuracy and coefficient of variation.

\section{RESULTS AND DISCUSSION}

The results obtained from the joint analysis of variance showed a significant difference between the genetic treatments for grain yield and the plant's height traits in both the generations, as well as for all other sources of variation (Table 2). Even though, the Genotype $x$ Environment (GxE) interactions were significant for both the traits, in this work, the results were based on the mean values of the environments, aiming to select the best populations for line extractions. Evaluating genotypes at several sites during a couple of years enabled the selection of the base population more assertively.

The grain yield means ranged from $5623\left(\mathrm{~kg} \mathrm{ha}^{-1}\right)$ to $7836\left(\mathrm{~kg} \mathrm{ha}^{-1}\right)$, the hybrids were allocated into three different groups by the Scott-Knott test (Table 3). For this trait, the hybrids AG1051, AG5055, AG8025,ALFA_9020C,
BG7046, and DKB455 showed the highest grain yield performance and the lowest by the hybrid 2B587. For plant height traits, four different groups were determined, in which mean plant height ranged from 1.89 to $2.19 \mathrm{~m}$ (Table 3).

Table 2: Summary of a joint analysis of variance for grain yield (GY) and plant height $(\mathrm{PH})$ traits for $\mathrm{F} 1$ and $\mathrm{F} 2$ generations of the 12 maize hybrids evaluated in four environments.

\begin{tabular}{|c|c|c|c|}
\hline \multirow{2}{*}{ FV } & \multirow{2}{*}{ GL } & \multicolumn{2}{|l|}{ QM } \\
\hline & & $\mathrm{GY}$ & $\mathrm{PH}$ \\
\hline Environments (E) & 3 & $32782598 * *$ & $1.33^{* *}$ \\
\hline Blocks/E/G & 12 & 1251535 & 0.02 \\
\hline Generations (G) & 1 & 380299021 ** & $2.86 * *$ \\
\hline$E * G$ & 3 & $2646166^{*}$ & $0.18^{* *}$ \\
\hline Hybrids (H) & 11 & $7950937 * \star$ & $0.21 * *$ \\
\hline$H^{*} \mathrm{E}$ & 33 & $2773591 * *$ & $0.03 *$ \\
\hline$H^{*} \mathrm{G}$ & 11 & $4439145^{* *}$ & $0.12^{* *}$ \\
\hline$H^{*} \mathrm{G} * \mathrm{E}$ & 33 & $2122355^{* *}$ & $0.04 * *$ \\
\hline Residual & 132 & 948295 & 0.02 \\
\hline General mean & & 6813.088 & 2.039242 \\
\hline
\end{tabular}

**, significant by $\mathrm{F}$ test at the level of $1 \%$; *, significant by $\mathrm{F}$ test at the level of $5 \%$.

Table 3: Grain yield (GY) and plant height (PH) means of the 12 maize hybrids in both generations, in four environments.

\begin{tabular}{ccccc}
\hline Hybrids & GY & & PH & \\
\hline AG1051 & 7183 & a & 2.11 & a \\
AG5055 & 7382 & a & 2.07 & b \\
AG8025 & 7836 & a & 2.05 & b \\
Alfa_9020C & 7265 & a & 2.14 & a \\
BG7046 & 7321 & a & 2.14 & a \\
BM810 & 6394 & b & 1.95 & c \\
2B587 & 5623 & c & 1.82 & d \\
DKB455 & 6970 & a & 1.98 & c \\
Impacto & 6254 & b & 2.01 & c \\
Omega & 6605 & b & 1.97 & c \\
PRE_32D10 & 6158 & b & 2.04 & b \\
RK3014 & 6767 & b & 2.19 & a \\
\hline
\end{tabular}

Means followed by the same letter in the columns belong to the same group by the Scott-Knott test (1974) to the level of $5 \%$ of probability.

Source: Authors (2019). 
The grain yield means in $\mathrm{F}_{1}$ generation for each environment ranged from $7287 \mathrm{~kg} \mathrm{ha}^{-1}$ to $8878 \mathrm{~kg} \mathrm{ha}^{-1}$, for Muquém (2017/18) and UFLA (2017/18) environments, respectively (Table 4). For the $\mathrm{F}_{2}$ generation, reductions in the grain yields, in comparison to the $\mathrm{F}_{1}$ generation, were observed. Due to the higher soil fertility of the UFLA site, the highest grain yield means were observed at this site for both the years. In addition, the greatest pest incidence was observed at Muquém compared to UFLA, which negatively affected the grain yield mean. According to Valicente et al. (2017), the plant diseases and insects, such as Spodoptera frugiperda, may reduce maize crop grain yielding up to $52 \%$ depending on plant stage, levels of infestation, and environment.

For plant height trait, the environments were divided into four different groups, in which the highest mean was observed in UFLA (2017-18) and the lowest mean in Muquém (2018-19) (Table 4).

It was possible to observe the significant difference for both the evaluated traits, in terms of means, between $F_{1}$ and $F_{2}$ generations. Data analysis showed a reduction of $2518 \mathrm{~kg} \mathrm{ha}^{-1}$ in grain yield mean for $F_{1}$ in relation to $F_{2}$ generations (Table 5). A similar pattern was observed in plant height trait, in which $\mathrm{F}_{2}$ generation showed a reduction of $22 \mathrm{~cm}$ in the plants' mean height.

The reductions of the means of both traits are due to the inbreeding depression phenomenon, in which the frequency of homozygous loci increases with about $50 \%$ in each self-fertilization round (Hallauer et al., 2010). This phenomenon causes a reduction in the adaptative value or mean of genotypes derived from crossing between related individuals, and it is dependent on the frequency of deleterious and lethal recessive alleles involved in the control of a given biological character (Freitas et al., 2016).

Based on the results of joint analysis of variance for $m+a$ and $d$ estimates, it was significant differences were observed for both the evaluated traits (Table 6).

Observing the $d$ estimates for grain yield and plant height traits, Muquém 2018/19 and UFLA 2018/19 showed higher means than the other. For $m+a$ estimates, the highest grain yield means were observed on UFLA and Muquém, both in 2017-18. However, the highest mean of plant height $m+a$ estimate was observed in Muqém 2017-18 (Table 4). This lack of coincidence is due to the presence of GxE interaction.

The comparisons between estimates of $m+a$ from different hybrids enabled us to classify them in relation to the mean frequency of favorable alleles that are in homozygosis. The higher the value of $m+a$, the higher the frequency of these alleles will be (Ramalho et al., 2012). Therefore, considering the estimate of $m+a$ for grain yield, the hybrids AG1051, AG8025, BG7046, DKB455, and OMEGA were the most promising hybrids for lines extraction for the trait in the study because of their higher mean of $m+a$ values. The hybrids AG8025 and BG7046 showed high values of $m+a$ and high means of grain yielding (Table 7). It was demonstrated by Abreu, Ramalho and Santos (2002) that there is a high correspondence between the $m+a$ estimates and the $\mathrm{F}_{\infty}$ generation. Thus the information obtained in this work showed the importance of these estimates for line extraction, aiming high grain yielding.

Table 4: Grain yield (GY) and plant height (PH) means of $\mathrm{F}_{1}$ and $\mathrm{F}_{2}$ generations, estimates of $m+a$ and $d$ components for grain yield ( $m+a \mathrm{GY}$ and $d \mathrm{GY}$ ) and plant height ( $m+a \mathrm{PH}$ and $d \mathrm{PH})$, for the four environments.

\begin{tabular}{|c|c|c|c|c|c|c|c|c|}
\hline \multirow[t]{2}{*}{ Environments } & \multicolumn{2}{|c|}{ GY } & \multicolumn{2}{|c|}{$\mathrm{PH}$} & \multirow{2}{*}{$d \mathrm{GY}$} & \multirow{2}{*}{$d \mathrm{PH}$} & \multirow{2}{*}{$m+a \mathrm{GY}$} & \multirow{2}{*}{$m+a \mathrm{PH}$} \\
\hline & F1 & $\mathrm{F} 2$ & F1 & F2 & & & & \\
\hline Muquém (2017/18) & $7287 b$ & $5264 c$ & $1.95 d$ & $1.75 d$ & $4047 b$ & $0.39 b$ & $3241 a$ & $1.55 \mathrm{c}$ \\
\hline UFLA (2017/18) & $8878 a$ & $6371 a$ & $2.18 c$ & $2.08 a$ & $5014 a$ & $0.20 c$ & $3864 a$ & $1.98 a$ \\
\hline Muquém (2018/19) & $7503 b$ & $4669 d$ & $2.24 b$ & $1.89 c$ & $5670 a$ & $0.69 a$ & $1834 c$ & $1.54 \mathrm{c}$ \\
\hline UFLA (2018/19) & $8609 a$ & $5651 b$ & $2.32 a$ & $2.02 b$ & $5917 a$ & $0.60 a$ & $2692 b$ & $1.72 b$ \\
\hline
\end{tabular}

${ }^{1}$ Means followed by the same letter in the same column do not differ among them by the Scott-Knott test (1974) at the level of $5 \%$ of probability.

Table 5: Grain yield (GY) and plant height $(\mathrm{PH})$ means of $\mathrm{F}_{1}$ and $\mathrm{F}_{2}$ generations in four environments.

\begin{tabular}{ccc}
\hline Generations & GY & PH \\
\hline F1 & $8072 \mathrm{a}$ & $2.15 \mathrm{a}$ \\
F2 & $5554 \mathrm{~b}$ & $1.93 \mathrm{~b}$ \\
\hline
\end{tabular}

Means followed by the same lower case letters in the columns do not differ among them by the F-test. Source: Authors (2019). 
Table 6: Summary of joint analysis of variance for the estimates of $m+a$ and $d$ components for grain yield ( $m+a \mathrm{GY}$ and $d \mathrm{GY}$ ) and plant height ( $m+a \mathrm{PH}$ and $d \mathrm{PH}$ ), involving the 12 commercial maize hybrids, in the four environments.

\begin{tabular}{crllll}
\hline \multirow{2}{*}{$\mathrm{FV}$} & $\mathrm{GL}$ & \multicolumn{5}{c}{$\mathrm{QM}$} \\
\cline { 3 - 6 } & & \multicolumn{1}{c}{$d \mathrm{GY}$} & \multicolumn{1}{c}{$m+a \mathrm{GY}$} & \multicolumn{1}{c}{$d \mathrm{PH}$} & $m+a \mathrm{PH}$ \\
\hline Environments $(\mathrm{E})$ & 3 & $21169346^{*}$ & $21238244^{* *}$ & $1.46^{* *}$ & $1.39^{* *}$ \\
Hybrids $(\mathrm{H})$ & 11 & $35513178^{* *}$ & $24607179^{* *}$ & $0.93^{* *}$ & $0.36^{* *}$ \\
Blocks/E & 6 & $15077398^{*}$ & $11397366^{* *}$ & $0.29^{*}$ & $0.18^{*}$ \\
$\mathrm{H}^{*} \mathrm{~A}$ & 33 & $16978837^{* *}$ & $12717760^{* *}$ & $0.30^{* *}$ & $0.22^{* *}$ \\
Residue & 66 & 6165516 & 2957705 & 0.11 & 0.07 \\
General mean & & 5035.2 & 3036.69 & 0.43617 & 1.71217 \\
\hline
\end{tabular}

**, significant by F-test at the level of $1 \%$; *, significant by F-test at the level of $5 \%$.

Table 7: Mean of $\mathrm{F}_{1}$ and $\mathrm{F}_{2}$ generations, estimates of $m+a$, and $d$, inbreeding depression for grain yield trait (GY), considering the four evaluation environments for the 12 evaluated hybrids.

\begin{tabular}{cccccccc}
\hline Hybrids & GY F1 & GY F2 & ID(\%) & $(\mathrm{m}+\mathrm{a}) \mathrm{GY}$ & $\%^{2}$ & (d) GY & $\%^{2}$ \\
\hline AG1051 & $7868 \mathrm{~b}$ & $6498 \mathrm{a}$ & 17.42 & $5126.89 \mathrm{a}$ & 65.16 & $2741.29 \mathrm{c}$ & 34.84 \\
AG5055 & $9372 \mathrm{a}$ & $5392 \mathrm{c}$ & 42.47 & $1411.26 \mathrm{~b}$ & 15.06 & $7960.51 \mathrm{a}$ & 84.94 \\
AG8025 & $8589 \mathrm{a}$ & $7083 \mathrm{a}$ & 17.53 & $5578.11 \mathrm{a}$ & 64.95 & $3010.66 \mathrm{c}$ & 35.05 \\
Alfa_9020C & $8888 \mathrm{a}$ & $5641 \mathrm{~b}$ & 36.53 & $2393.90 \mathrm{~b}$ & 26.93 & $6494.55 \mathrm{a}$ & 73.07 \\
BG7046 & $8601 \mathrm{a}$ & $6041 \mathrm{~b}$ & 29.77 & $3480.27 \mathrm{a}$ & 40.46 & $5120.93 \mathrm{~b}$ & 59.54 \\
BM810 & $7686 \mathrm{~b}$ & $5102 \mathrm{c}$ & 33.62 & $2517.54 \mathrm{~b}$ & 32.75 & $5168.47 \mathrm{~b}$ & 67.25 \\
2B587 & $6766 \mathrm{~b}$ & $4480 \mathrm{c}$ & 33.78 & $2194.54 \mathrm{~b}$ & 32.44 & $4571.26 \mathrm{~b}$ & 67.56 \\
DKB455 & $7829 \mathrm{~b}$ & $6112 \mathrm{~b}$ & 21.94 & $4393.78 \mathrm{a}$ & 56.12 & $3435.48 \mathrm{c}$ & 43.88 \\
Impacto & $7836 \mathrm{~b}$ & $4672 \mathrm{c}$ & 40.38 & $1507.47 \mathrm{~b}$ & 19.24 & $6328.07 \mathrm{a}$ & 80.76 \\
Omega & $7305 \mathrm{~b}$ & $5905 \mathrm{~b}$ & 19.16 & $4505.70 \mathrm{a}$ & 61.68 & $2799.06 \mathrm{c}$ & 38.32 \\
PRE_32D10 & $7330 \mathrm{~b}$ & $4986 \mathrm{c}$ & 31.97 & $2642.72 \mathrm{~b}$ & 36.05 & $4687.09 \mathrm{~b}$ & 63.95 \\
RK3014 & $8793 \mathrm{a}$ & $4741 \mathrm{c}$ & 46.09 & $688.07 \mathrm{~b}$ & 7.83 & $8105.08 \mathrm{a}$ & 92.17 \\
General Mean & 8072 & 5554 & 30.89 & 3036.69 & 38.22 & 5035.20 & 61.78 \\
\hline
\end{tabular}

${ }^{1}$ Means followed by the same letter in the same column do not differ among them by the Scott-Knott test (1974) at the level of $5 \%$ of probability.

2 Percentage contribution of $\mathrm{m}+\mathrm{a}$ and $\mathrm{d}$ for the manifestation of the character obtained from the expressions $\left[(m+a) \div \overline{F_{1}}\right] \times 100$ and $\left[(d) \div \overline{F_{1}}\right] \times 100$.

Source: Authors (2019).

For the estimates of $d$ for grain yield, the highest values were observed in the hybrids AG5055, ALFA_9020C, IMPACTO, and RK3014. Considering the loci have an equal contribution, the $d$ estimate provided information about the frequency of heterozygous loci. In other words, the higher the $d$ estimate, the higher the number of loci in heterozygosis will be so will be the variation. According to Abreu, Ramalho and Santos (2002), this association between the estimate of $d$ and heterosis was positive and high $(r=0.95)$, indicating an association between the estimate of $d$ and genetic variance.

For grain yield there was higher contribution, on an average, for $d$ estimate, and it contributed with $61.78 \%$ for the grain yield performance of the hybrids, while $m+a$ contributed with $38.22 \%$ (Table 7). Earlier, Ramalho et al. (2012), showed similar results when making a compilation of works from the year 1987-2001. 
Once the values of $d$ are associated with heterozygosis, that is worth highlighting since the contribution of heterosis has been decreasing through the years, while the increase in the productivity per se of the lines (Troyer; Wellin, 2009). From 1905 to 2005, the lines' productivity increased from 1.9 to 3.5 times faster than the contribution of heterosis. Likewise, the contribution of the lines in the production of commercial hybrids increased (Ramalho et al., 2012). Despite the importance of the heterosis in the hybrids mean, the additive effects, like higher values of $m+a$ estimates, should be considered in the choice of the base population for the plant breeding program.

When considering the contribution of the estimates for plant height, it is observed on an average, as a higher contribution of $m+a(80.43 \%)$ in relation to $d(19.57 \%)$ (Table 8). Similar results were reported by several authors demonstrating that this characteristic has a greater influence of additive effects than others (Oliveira et al., 2020; Somera et al., 2018; Viana et al., 2009).

On the other hand, considering plant height traits, lower estimates of $m+a$ are desirable, since lower plants increase the plant populations per hectare without having problems with topping and/or lodging, which makes the mechanical harvest difficult. Lower values of $m+a$ were observed for the hybrids AG5055 and ALFA 9020C, followed by the hybrids AG1051, AG8025, and DKB455, which also showed high values of $\mathrm{m}+\mathrm{a}$ for grain yield (Table 8). In the case of an estimate of $d$, higher values were observed for the hybrids AG5055 and ALFA 9020C.

The inbreeding depression (ID\%) for the grain yield trait was, on an average, $30.89 \%$, and it ranged from 17.42 to $46.09 \%$ for the hybrids AG1051 and RK3014, respectively (Table 7). Other results corroborate with the values obtained in this work (Oliveira et al., 2020; Somera et al., 2018).

The hybrids showed a lower percentage of inbreeding depression for characteristic plant height, on an average of $9.79 \%$, varying from 0.77 to $21.27 \%$ (Table 8 ). Similar values to these were observed by Senhorinho et al. (2015); and Tolentino et al. (2017).

The variation in inbreeding depression is related to different levels of dominance, allele frequency, the relationship between genotypes, and the characteristics under study (Hallauer et al., 2010). The present study showed that grain yield trait had higher inbreeding depression, emphasizing the higher level of dominance related to this trait.

Table 8: Mean of F1 and F2 generations, estimates of $m+a, d$, inbreeding depression for plants height trait (PH), considering the four evaluation environments for the twelve evaluated hybrids.

\begin{tabular}{cccccccc}
\hline Hybrids & PH F1 & PH F2 & ID $(\%)$ & $(\mathrm{m}+\mathrm{a}) \mathrm{PH}$ & $\%^{2}$ & (d) PH & $\%^{2}$ \\
\hline AG1051 & $2.27 \mathrm{a}^{1}$ & $1.96 \mathrm{~B}$ & 13.76 & $1.64 \mathrm{~b}$ & 72.35 & $0.63 \mathrm{~b}$ & 27.65 \\
AG5055 & $2.31 \mathrm{a}$ & $1.82 \mathrm{C}$ & 21.27 & $1.33 \mathrm{c}$ & 57.46 & $0.98 \mathrm{a}$ & 42.54 \\
AG8025 & $2.21 \mathrm{a}$ & $1.89 \mathrm{C}$ & 14.27 & $1.58 \mathrm{~b}$ & 71.47 & $0.63 \mathrm{~b}$ & 28.53 \\
Alfa_9020C & $2.36 \mathrm{a}$ & $1.91 \mathrm{C}$ & 19.05 & $1.46 \mathrm{c}$ & 61.94 & $0.90 \mathrm{a}$ & 38.06 \\
BG7046 & $2.26 \mathrm{a}$ & $2.02 \mathrm{~B}$ & 10.74 & $1.78 \mathrm{a}$ & 78.52 & $0.49 \mathrm{~b}$ & 21.48 \\
BM810 & $2.02 \mathrm{~b}$ & $1.89 \mathrm{C}$ & 6.49 & $1.76 \mathrm{a}$ & 87.07 & $0.26 \mathrm{c}$ & 12.93 \\
2B587 & $1.83 \mathrm{c}$ & $1.81 \mathrm{C}$ & 0.77 & $1.80 \mathrm{a}$ & 98.52 & $0.03 \mathrm{c}$ & 1.48 \\
DKB455 & $2.10 \mathrm{~b}$ & $1.86 \mathrm{C}$ & 11.57 & $1.61 \mathrm{~b}$ & 76.82 & $0.49 \mathrm{~b}$ & 23.18 \\
Impacto & $2.06 \mathrm{~b}$ & $1.97 \mathrm{~B}$ & 4.28 & $1.88 \mathrm{a}$ & 91.49 & $0.18 \mathrm{c}$ & 8.51 \\
Omega & $2.01 \mathrm{~b}$ & $1.94 \mathrm{~B}$ & 3.78 & $1.86 \mathrm{a}$ & 92.54 & $0.15 \mathrm{c}$ & 7.46 \\
PRE_32D10 & $2.08 \mathrm{~b}$ & $2.00 \mathrm{~B}$ & 3.99 & $1.91 \mathrm{a}$ & 92.01 & $0.17 \mathrm{c}$ & 7.99 \\
RK3014 & $2.27 \mathrm{a}$ & $2.10 \mathrm{~A}$ & 7.52 & $1.93 \mathrm{a}$ & 84.96 & $0.34 \mathrm{c}$ & 15.04 \\
\hline General Mean & 2.15 & 1.93 & 9.79 & 1.71 & 80.43 & 0.44 & 19.57 \\
\hline
\end{tabular}

${ }^{1}$ Means followed by the same letter in the same column do not differ among them by the Scott-Knott test (1974) at the level of $5 \%$ of probability.

2 Percentage contribution of $m+a$ and $d$ for the manifestation of the character obtained by the expressions $\left[(m+a) \div \bar{F}_{1}\right] \times 100$ and $\left[(d) \div \overline{F_{1}}\right] \times 100$.

Source: Authors (2019). 
For the grain yield, the dominance effects have a greater contribution; thus the selection based only in the general hybrids means is not a good criterion for choosing the populations for line inbred line extraction. Likewise, the estimate of $m+a$ has to be considered once it will provide information about the mean of $\mathrm{F}_{\infty}$ generation. On the other hand, the $d$ estimate provides the number of loci in heterozygosis and the genetic variation. Thus, considering the estimates of $m+a$, the hybrids AG1051, AG8025, BG7046, DKB455, and OMEGA were the most promising ones for the inbred lines extraction for the characteristic in study due to the fact of showing higher $m+a$ estimates. Highlighting the hybrid AG8025 and BG7046, which presented high values of $m+a$ and high grain yield means, once the ideal is to associate both. In relation to the plant height trait, there was a higher contribution of additive effects. Aiming the development of lines that will provide lower height and high grain yielding hybrids, the superiority of the hybrid AG8025 must be reinforced, being the most promising hybrid for inbred lines as it showed higher values of $m+a$ estimates and grain yield, besides showing the third lower value of $m+a$ for plant height.

\section{CONCLUSIONS}

For the grain yield trait, there was a greater contribution of dominance effects in the hybrids mean, whereas, on the other hand, there was a greater contribution of additive effects for plant height. Also, there was greater inbreeding depression for grain yield than for plant height. The hybrids AG1051, AG8025, BG7046, DKB455, and OMEGA were the most promising ones for the inbred line extraction. Highlighting the hybrids AG8025 and BG7046, which also had high grain yield means.

\section{ACKNOWLEDGMENTS}

Financial support was provided by the Coordination of Improvement of Higher Education Personnel (CAPES) Foundation and the National Council of Scientific and Technological Development (CNPq).

\section{REFERENCES}

ABREU, A. D. F. B.; RAMALHO, M. A. P.; SANTOS, J. B. D. Prediction of seed-yield potential of common bean populations. Genetics and Molecular Biology, 25(3):323-327, 2002.

COMPANHIA NACIONAL DE ABASTECIMENTO - CONAB. Acompanhamento da Safra Brasileira Grãos: Safra 2018/19. 2019. Brasília. Available in: <https://www.conab.gov.br/>. Access in: August, 2, 2019.
MENDIBURU, F. de. Agricolae: Statistical procedures for agricultural research. R package, version 1.3-3. 2019. Available in: <https://cran.r-project.org/web/packages/agricolae/index. html>. Access in: August, 17, 2020.

FREITAS. J. P. X. et al. Inbreeding depression in cassava for productive traits. Euphytica, 208:1-9: 2016.

HALLAUER. A. R. et al. Quantitative genetics in maize breeding. New York: Springer. 2010, 664p.

KUKI, M. C. et al. Inbreeding depression and mean genetic components in green corn genotypes. Ciência Rural, 47(5):1-6, 2017.

OLIVEIRA, A. S. et al. Inbreeding depression and genetic variability in agricultural traits and in resistance to plant pathogens in exotic maize populations. Bioscience Journal, 36(3):914-923, 2020.

R DEVELOPMENT CORE TEAM. A Language and environment for statistical computing. 2019. Vienna, Austria. Available in: < http://www.R-project.org/>. Access in: August, 17, 2019.

RAMALHO, M. A. P. et al. Aplicações da genética quantitativa no melhoramento de plantas autógamas. 1.ed. Lavras: Ed. UFLA, 2012, 522p.

SCOTT, A. J.; KNOTT, M. A. A cluster analysis method for grouping means in the analysis of variance. Biometrics, 30(3):507$512,1974$.

SENHORINHO, H. J. C. et al. Combining abilities and inbreeding depression in commercial maize hybrids capacidades combinatórias e depressão por endogamia de híbridos comerciais de milho. Ciências Agrárias, 36(6):4133-4150, 2015.

SOMERA, A. et al. Inbreeding depression and performance of partially self-fertilized maize progenies in a top cross. Chilean Journal of Agricultural Research, 78(3):318-326, 2018.

TOLENTINO, V. H. D. et al. Diallel analysis and inbreeding depression of commercial maize hybrids aiming the formation of base populations. Maydica, 62(1):1-7, 2017.

TROYER, A. F.; WELLIN, E. J. Heterosis decreasing in hybrids: Yield test inbreds. Crop Science, 49:1949-1969, 2009.

VALICIENTE, F. H. Manejo de pragas. In: BORÉM, A.; GALVÃO, J. C. C.; PIMENTEL, M. A. Milho do plantio à Colheita. 2.ed. Viçosa: Ed. UFV, p.278-298, 2017.

VENCOVSKY, R.; CRUZ, C. D. Comparação de métodos de correção de rendimento de parcelas experimentais com estandes variados: I. Dados simulados. Pesquisa Agropecuária Brasileira, 26(5):647-657, 1991.

VIANA, L. F. et al. Predição de médias de linhagens obtidas de híbridos Single-cross de milho (Zea mays L.). Ciência e Agrotecnologia, 33:1999-2004, 2009. 